\title{
PKM PRODUKSI DAN PEMASARAN HASIL OLAHAN PEPAYA DI BABADAN POLENGAN SRUMBUNG MAGELANG
}

\author{
Barbara Gunawan \\ Fakultas Ekonomi dan Bisnis, Universitas Muhammadiyah Yogyakarta \\ Jl. Brawijaya Kasihan, Bantul, Yogyakarta \\ email: era@umy.ac.id
}

\begin{abstract}
Abstrak
Target program PKM ini adalah sekelompok orang yang produktif secara ekonomi (usaha kecil). Program ini bertujuan untuk mengembangkan komunitas yang mandiri secara ekonomi. Mitra bisnis dalam program ini adalah usaha kecil membuat dan memasarkan produk pepaya olahan. Masalah yang dihadapi oleh mitra adalah 1) Kualitas produk yang tidak begitu baik, 2) Kemasan produk masih terlalu sederhana, 3) Tidak ada label produk, 4) Tidak ada PIRT, 5) Tidak ada papan nama, 6) Tidak ada media promosi, dan 7) Mitra tidak membuat laporan keuangan.

Hasil yang dihasilkan dari program layanan masyarakat pemasaran PKM yang dihasilkan oleh Papaya di Babadan Polengan Srumbung Magelang adalah 1) Kualitas produk dengan kemasan yang elegan, 2) Label produk stiker, 3) Produk dengan PIRT, 4) Papan Nama, 5) Facebook dan Instagram, 6) Laporan keuangan.

Metode yang digunakan untuk mencapai tujuan ini adalah 1) Pelatihan dalam membuat permen pepaya, 2) Pengadaan kemasan plastik dan alat cup sealer 3) Membuat stiker label produk, 4) Membuat PIRT, 5) Membuat papan nama, 6) Membuat akun Facebook dan Instagram untuk mitra, 7) Pelatihan manajemen pemasaran, dan 8) Pelatihan dan bimbingan dalam persiapan laporan keuangan.
\end{abstract}

Kata kunci: Papaya Manisan, Usaha Kecil, Polengan

\section{Abstract}

The target of this PKM program is a group of people who are economically productive (small businesses). The program aims to develop economically independent communities. Business partners in this program are small businesses making and marketing processed papaya products. The problems faced by partners are 1) Product quality that is not so good, 2) Product packaging is still too simple, 3) No product label, 4) No PIRT, 5) No signboard, 6) No promotional media, and 7) Partners do not make financial reports.

Outcomes generated from the PKM marketing community service program produced by Papaya in Babadan Polengan Srumbung Magelang are 1) Quality products with elegant packaging, 2) Product label stickers, 3) Products with PIRT, 4) Nameplate, 5) Facebook and Instagram, 6) Financial Statements.

The method used to achieve this goal is 1) Training in making papaya sweets, 2) Procurement of plastic packaging and cup sealer tools 3) Making product label stickers, 4) Making PIRT, 5) Making nameplate, 6) Making Facebook and Instagram accounts for partners, 7) Marketing management training, and 8) Training and mentoring in the preparation of financial reports.

Keywords: Papaya Candied, Small Business, Polengan 


\section{PENDAHULUAN Analisis Situasi}

Polengan merupakan kumpulan beberapa pedukuhan yang berada di kaki Gunung Merapi bagian barat, sekitar 11 kilo meter dari puncak gunung Merapi. Desa Polengan membawahi sebanyak tujuh dusun yang terdiri dari Babadan, Lembar, Larangan, Gejayan, Polengan, Kronggahan, dan Gowok. Luas wilayah desa Polengan $\pm 4 \mathrm{~km} 2$, dimana lebih dari enam puluh persen adalah lahan pertanian. Selain padi dan sayur-mayur, komoditas yang saat ini dibudidayakan dan berkembang pesat adalah pepaya jenis California. Seiring semakin banyaknya masyarakat yang membudidayakan tanaman pepaya, maka tak jarang buah papaya sangat melimpah karena terjadi panen raya secara serentak di desa tersebut. Melimpahnya panen raya pepaya California berakibat pada jatuhnya harga pepaya di pasaran, hal ini menjadi dilema tersendiri bagi petani. Harga pepaya yang terlalu rendah tidak memberikan banyak penghasilan bagi masyarakat petani pepaya. Pada bagian lain melimpahnya pepaya pada saat panen raya memaksa petani untuk segera menjual habis hasil panennya pada harga yang lebih rendah agar tidak merugi sebagai akibat hasil panen yang membusuk.

Pada masa setelah panen raya harga pepaya biasanya akan membaik akan tetapi produksi yang tidak banyak tidak memberikan penghasilan yang memadai bagi petani pepaya. Dibutuhkan inovasi pengolahan pepaya yang memberikan nilai ekonomis lebih bagi pepaya yang tidak sulit dilakukan namun berdaya tahan (shelf life) lebih lama sehingga memudahkan dalam penanganan produk.

Pepaya merupakan salah satu buah yang populer di Indonesia, harganya relatif murah, dapat dimakan secara langsung atau diolah menjadi campuran es buah atau manisan. Di Indonesia, manisan pepaya lazim disajikan sebagai menu makanan penutup. Manisan pepaya juga dapat dijadikan oleh-oleh atau bisa juga untuk hidangan dalam berbagai acara baik yang formal maupun informal.

Masyarakat desa Polengan sudah bisa menangkap peluang bisnis dari melimpahnya Pepaya yang terdapat di Desa Polengan, hal itu tampak dari adanya industri rumah tangga berupa pengolahan pepaya menjadi manisan. Industri olahan pepaya yang terdapat di Desa Polengan dikelola oleh kelompok PKK Dusun Polengan yang dipimpin oleh Ibu Ristinah yang baru saja merintis bisnisnya di akhir 2017.

Saat ini penjualan produk dilakukan dengan cara menitipkan manisan pepaya ke pasar-pasar dan warung-warung dengan cara mengemas dalam kemasan plastik. Melihat kemasan yang terlalu sederhana dan mekanisme pemasaran yang sangat konvensional, maka perlu kiranya dilakukan upaya agar produk manisan pepaya hasil olahan warga Dusun Babadan Polengan dapat dipasarkan secara lebih luas agar memberi keuntungan sebagaimana mestinya. Manisan pepaya buatan kelompok PKK Dusun Babadan ini juga diharapkan dapat menjadi alternatif oleholeh wisatawan domestik yang berkunjung ke Desa Polengan Magelang.

Adanya usaha pembuatan manisan pepaya diharapkan juga dapat meningkatkan penghasilan masyarakat sekaligus mengurangi jumlah pengangguran, mengingat angka kemiskinan dan tingkat pengangguran, serta kesenjangan sosial yang masih tinggi di Indonesia.(Harahap, 2016)

Penciptaan sektor ekonomi yang kuat dan upaya meningkatkan pendapatan melalui penguatan sektor riil dan menciptakan lapangan kerja harus mulai diinisiasi (Yatim, 2015). Pembangunan hendaknya sesuai dengan potensi dan aspirasi masyarakat. JIka pelaksanaan prioritas pembangunan tidak sesuai dengan potensi yang dimiliki daerah, maka pemanfaatan sumber daya yang ada menjadi tidak optimal. (Badri, 2015) 


\section{Aspek produksi Mitra Usaha}

Produksi mitra adalah manisan pepaya bahan pokoknya terdiri dari Buah pepaya yang masih mengkal, Garam $10 \mathrm{~g}$, Gula pasir 600g, Asam askorbat 1g, Natrium bisulfit 1g, dan Air bersih 2 liter Alat yang digunakan adalah pisau yang cukup tajam untuk memotong buah pepaya, talenan bersih untuk alas saat memotong buah pepaya. Baskom plastik digunakan sebagai tempat merendam buah pepaya yang sudah dipotongpotong. Panci anti karat yang digunakan untuk merebus buah pepaya, sendok, saringan, dan kompor gas yang digunakan untuk memasak. Mitra sudah mempunyai sarana produksi yang memadai, karena memang untuk mengolah buah pepaya menjadi manisan pepaya tidak diperlukan peralatan khusus.

Tabel 1. Jenis Barang Produksi

\begin{tabular}{|l|l|l|l|}
\hline $\begin{array}{l}\text { Nama } \\
\text { Mitra }\end{array}$ & $\begin{array}{l}\text { Nama } \\
\text { produk }\end{array}$ & $\begin{array}{l}\text { Harga } \\
\text { / } \\
\text { porsi } \\
(\mathrm{Rp})\end{array}$ & $\begin{array}{l}\text { Rata/rata } \\
\text { penjualan } \\
\text { per bulan } \\
(\mathrm{Rp})\end{array}$ \\
\hline $\begin{array}{l}\text { Kel. IRT } \\
\text { Manisan } \\
\text { Pepaya }\end{array}$ & $\begin{array}{l}\text { Manisan } \\
\text { Pepaya }\end{array}$ & 1000 & 1.500 .000 \\
\hline
\end{tabular}

Peralatan yang sudah ada dan dapat digunakan terdiri dari 1 unit Kompor Gas, 2 unit Panci anti karat, 5 unit talenan, 10 unit pisau, 10 unit baskom plastic, dan 5 unit saringan.

\section{Tinjauan Pustaka Pemasaran}

(Kotler \& Amstrong, 2012) menyatakan bahwa "The process by which companies create value for customer and build strong relationship with customers in order to capture value from customers in return. (Buchari, 2009) menyatakan pemasaran sebagai penekanan pada analisis struktur pasar, orientasi, dan dukungan dari pelanggan, serta memosisikan perusahaan dalam mengawasi rantai nilai.

\section{Bauran Pemasaran}

Bauran pemasaran (Marketing mix) memiliki peranan yang penting dalam memengaruhi konsumen supaya membeli produk dan atau jasa yang ditawarkan produsen. Bauran pemasaran terdiri dari beberapa variabel yang dapat dikontrol oleh perusahaan dengan tujuan memuaskan pelanggan. (Kotler \& Amstrong, 2012) mendefinisikan "Marketing mix is good marketing tool is a set of products, pricing, promotion, distribution, combined to produce the desired response of the target market.

Dalam marketing mix terdapat seperangkat alat pemasaran yang populer disebut 4P, yaitu product (produk), price (harga), place (tempat atau saluran distribusi), dan promotion (promosi), pada pemasaran jasa terdapat alat pemasaran tambahan yaitu people (orang), physical evidence (fasilitas fisik), dan process (proses), yang kemudian memunculkan istilah 7P. Dengan demikian dapat disimpulkan marketing mix jasa terdiri dari product, price, place, promotion, people, physical evidence, and process.

\section{Identifikasi dan Perumusan Masalah}

Konsumen dari mitra usaha saat ini adalah warga sekitar Desa Polengan. Konsumen mengenal produk hanya ketika berbelanja di warung. Pendapatan mitra juga hanya terbatas dari penjualan di lokasi sekitar Polengan, padahal jika produk tersebut dipromosikan maka tidak menutup kemungkinan Mitra akan bisa mengembangkan bisnisnya. Saat ini Mitra belum melakukan promosi yang cukup untuk menjual produknya, tidak pula melakukan pencatatan selain menghitung belanja dan omzet.

Permasalahan yang dihadapi oleh mitra adalah:

1. Kualitas produk yang belum begitu bagus, belum ada quality control, rasa manisnya belum stabil, daya tahan produk belum begitu diperhatikan

2. Kemasan produk masih terlalu sederhana, hanya menggunakan plastik klip sederhana sehingga tampilan produk kurang menarik 
3. Belum ada label produk, sehingga calon konsumen belum bisa mengenali produk dengan mudah.

4. Belum ada kode PIRT (Produk Industri Rumah Tangga)

5. Tidak mempunyai papan nama mitra sehingga konsumen sulit mengenali produk dan penjual

6. Tidak ada media promosi, padahal ada potennsi besar bagi Mitra untuk meningkatkan omzet penjualan jika diadakan promosi dan

7. Mitra tidak membuat laporan keuangan, hanya catatan belanja sederhana saja.

8. Berdasarkan penjelasan tersebut maka rumusan masalahnya adalah bagaimana cara membuat manisan pepaya yang berkualitas dan bagaimana cara memasarkan produk tersebut?

\section{Tujuan Kegiatan}

Tujuan kegiatan ini adalah:

1. Memberikan pendampingan dan pelatihan tentang cara membuat manisan pepaya yang berkualitas hingga memperoleh PIRT

2. Memberikan pendampingan dan peatihan tentang cara pengemasan produk manisan pepaya

3. Memberikan pendampingan dan pelatihan tentang cara memasarkan produk manisan pepaya

4. Memberikan pelatihan dan pendampingan penghitungan harga pokok produksi dan penyusunan laporan keuangan

\section{Manfaat Kegiatan}

Bagi masyarakat dusun Babadan umumnya dan Ibu-ibu PKK Dusun Babadan khususnya, kegiatan PPM ini diharapkan dapat memberi manfaat berupa pengetahuan tentang cara pembuatan manisan pepaya, cara pengemasan produk, cara memasarkan, hingga cara membuat laporan keuangan. Dengan kegiatan tersebut maka Ibu-ibu PKK Dusun Babadan dapat melakukan kegiatan yang bernilai positif dan menambah penghasilan keluarga.

\section{METODE PENELITIAN Khalayak Sasaran}

Awalnya tim pengabdi melakukan observasi ke Dusun Babadan Polengan Magelang, kemudian Pengabdi melakukan wawancara dengan Lurah, Kepala Dusun, ketua PKK Dusun, dan warga. Pengabdi juga melihat potensi yang ada di Dusun Babadan. Setelah observasi dilakukan, dilanjutkan dengan memilih mitra yang berminat dan layak bekerjasama dengan tim pengabdi, dalam hal ini adalah Ketua Tim PKK yang memang sudah merintis usaha yang disepakati dan sesuai dengan aspirasi warga. Setelah melalui berbagai pertimbangan kelayakan, maka sasaran pada kegiatan pengabdian ini adalah usaha pembuatan dan penjualan manisan pepaya milik Kelompok PKK Dusun Babadan Polengan yang berlokasi di Dusun Babadan, Desa Polengan, Magelang, Jawa Tengah.

\section{Metode Kegiatan}

Untuk memecahkan permasalahan yang sudah diidentifikasi dan dirumuskan sebelumnya, supaya proses pendampingan berjalan dengan lancar maka sebagai alternatif pemecahan masalah adalah dengan melakukan pendampingan secara berkelompok, meliputi pelatihan produksi pembuatan manisan, pembuatan materi promosi, pelatihan mekanisme pemasaran, dan pelatihan penyusunan laporan keuangan. Adapun metode yang digunakan adalah:

\section{Demonstrasi}

Metode ini digunakan untuk menunjukkan tahap-tahap pembuatan manisan pepaya. Demonstrasi dilakukan oleh tim pelatih di hadapan peserta hingga peserta dapat mengamati secara langsung metode dan teknik yang digunakan, untuk selanjutnya peserta melakukan praktik sejak awal dari pengupasan sampai pengemasan.

Ceramah bervariasi 
Ceramah bervariasi adalah metode mengajar yang menuntut banyak keterlibatan peserta. Peserta dituntut untuk aktif berinteraksi, berdiskusi, sekaligus praktik. Metode ceramah dengan variasi dipilih untuk menyampaikan konsep-konsep yang penting untuk dipahami dan dikuasai oleh seluruh peserta pelatihan. Metode ini diterapkan dengan pertimbangan bahwa metode ceramah yang dikombinasikan dengan variasi gambar, animasi, dan display dapat memberikan materi secara lebih efektif dan efisien.

Materi yang diberikan meliputi: pelatihan produksi, mekanisme pemasaran baik secara konvensional maupun online, dan pelatihan penyusunan laporan keuangan yang diawali dengan penentuan harga pokok produksi.

\section{Latihan}

Metode ini digunakan untuk memberikan tugas kepada peserta pendampingan untuk mempraktikkan pembuatan manisan pepaya dan pengemasan yang memenuhi standard yang layak jual.

\section{Langkah-Langkah Kegiatan}

\section{Aspek Produksi}

Mengadakan pelatihan pembuatan manisan pepaya dengan memperhatikan kualitas produksi dan rasa. Pelatihan pembuatan manisan pepaya dipandu oleh instruktur yang sudah berpengalaman dalam pembuatan dan bisnis manisan salak yang ada di Dusun Babadan. Kegiatan latihan dilakukan beberapa kali hingga didapatkan komposisi yang pas, rasa yang enak, dan penampilan yang menarik.

\section{Aspek Pemasaran}

Untuk menyelesaikan permasalahan Mitra, maka solusi yang dilakukan untuk menyelesaikan permasalahan pemasaran produk adalah:

a.Pelatihan manajemen pemasaran

b.Membuat label produk

\section{c. Membuat PIRT}

d.Pembuatan plang papan nama Mitra

e.Pembuatan akun facebook dan Instagram untuk Mitra

f. Pelatihan Akuntansi/Manajemen keuangan

Dalam program ini, penulis membuatkan akun social media mengingat ada perubahan gaya hidup masyarakat dan memang kebudayaan audiovisual sudah menjadi kenyataan yang tak terelakkan tengah masyarakat.(Dwita, 2015). Aspek kegiatan dan target luaran disajikan pada Tabel 3.

Tabel 3 Aspek Kegiatan dan Target Luaran

\begin{tabular}{|c|c|c|}
\hline $\begin{array}{l}\text { ASPEK } \\
\text { KEGIATAN }\end{array}$ & $\begin{array}{l}\text { TARGET } \\
\text { LUARAN }\end{array}$ & SPESIFIKASI \\
\hline $\begin{array}{l}\text { Peningkatan } \\
\text { kualitas } \\
\text { produk }\end{array}$ & $\begin{array}{l}\text { Produk } \\
\text { berkualitas }\end{array}$ & $\begin{array}{ll}\text { Rasa } & \text { enak, } \\
\text { kualitas baik, } & \text { dan daya } \\
\text { prohan } \\
\text { meduk }\end{array}$ \\
\hline $\begin{array}{l}\text { Pengadaan } \\
\text { cup sealer dan } \\
\text { cup plastic }\end{array}$ & $\begin{array}{l}\text { Produk } \\
\text { dengan } \\
\text { kemasan } \\
\text { yang } \\
\text { menarik }\end{array}$ & $\begin{array}{l}\text { Produk akan } \\
\text { dikemas dengan } \\
\text { menarik } \\
\text { sehingga pantas } \\
\text { dijadikan } \\
\text { alternative oleh- } \\
\text { oleh. }\end{array}$ \\
\hline $\begin{array}{l}\text { Peningkatan } \\
\text { promosi }\end{array}$ & $\begin{array}{l}\text { Menjadikan } \\
\text { tempat usaha } \\
\text { lebih tertata } \\
\text { rapi dan } \\
\text { tersedia } \\
\text { media } \\
\text { promosi }\end{array}$ & $\begin{array}{l}\text { Membuat plang } \\
\text { papan nama } \\
\text { untuk promosi } \\
\text { Membuat akun } \\
\text { facebook dan } \\
\text { Instagram }\end{array}$ \\
\hline $\begin{array}{l}\text { Perbaikan } \\
\text { manajemen } \\
\text { keuangan dan } \\
\text { akuntansi }\end{array}$ & $\begin{array}{l}\text { Pemahaman } \\
\text { pengelolaan } \\
\text { administrasi } \\
\text { keuangan } \\
\text { yang baik }\end{array}$ & $\begin{array}{l}\text { Pelatihan } \\
\text { pembuatan } \\
\text { catatan/ laporan } \\
\text { keuangan }\end{array}$ \\
\hline $\begin{array}{l}\text { Memperluas } \\
\text { jangkauan } \\
\text { pasar }\end{array}$ & \begin{tabular}{ll}
\multicolumn{2}{l}{ Menambah } \\
target & pasar \\
yang & lebih \\
luas &
\end{tabular} & $\begin{array}{l}\text { Pelatihan } \\
\text { manajemen } \\
\text { pemasaran }\end{array}$ \\
\hline
\end{tabular}

Faktor Pendukung dan Penghambat

Kegiatan didukung oleh segenap aparat, tim penggerak PKK Dusun Babadan, Ibu-ibu, dan para remaja yang mempunyai keinginan kuat untuk 
mengembangkan produk sehingga bisa menjadi produk yang dpat dijual secara luas.

Adapun hambatan yang dihadapi dalam melakukan pemasaran online adalah sinyal internet di Dusun Polengan kurang bdan kurang lancar, sehingga untuk memasarkan produk melalui media online bukan merupakan hal yang mudah. Hambatan berikutnya adalah Ibibu PKK Dusun Polengan mayoritas belum bisa mengoperasikan media sosial dengan baik.

\section{HASIL DAN PEMBAHASAN \\ Hasil Pelaksanaan Kegiatan}

1. Pelatihan Pembuatan Manisan Pepaya

Pelatihan dilakukan beberapa kali, karena pada percobaan pertama dan kedua gagal, maka dilaksanakan percobaan ketiga. Pada percobaan pertama hasilnya manisan pepaya terlalu lembek dan tidak awet. Pada pelatihan kedua hasilnya sudah lebih baik, namun rasanya masih belum stabil, akhirnya dilakukan pelatihan produksi yang ketiga, sehingga didapatkan formula dan bentuk yang pas dan bagus. Dalam perkembangannya Mitra yang sangat antusias dalam belajar dan memproduksi kemudian juga berlatih membuat manisan nangka dan manisan salak. Sehingga Mitra juga membuat, mengemas, dan menjual manisan nangka dan manisan salak sebagai produk pendamping. Pelatihan didampingi oleh tim yang memang kompeten dan berpengalaman dalam pembuatan manisan.

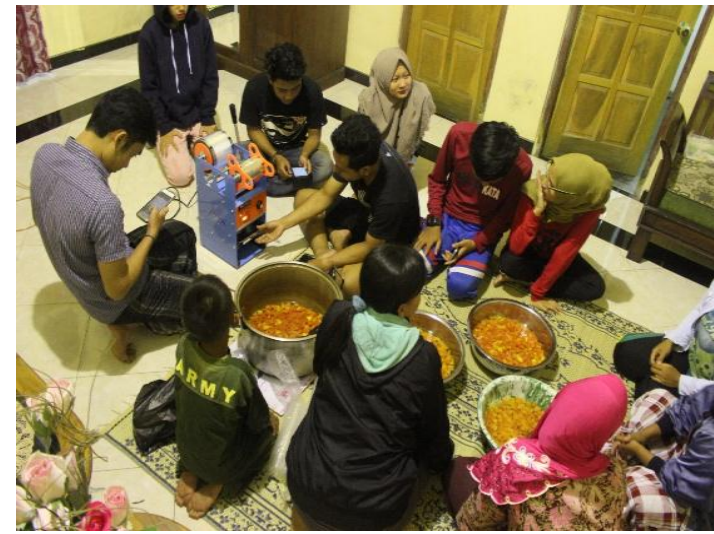

Gambar 2 Pelatihan Pembuatan Manisan Pepaya

Cara Produksi dan Pengemasan

a. Kupas buah pepaya, buang bijinya lalu belah memanjang, selanjutnya potong menurut selera dan cuci hingga bersih.

b. Larutkan 10 gram garam dalam 1 liter air bersih lalu rendam potongan buah pepaya tersebut dalam air garam semalaman. Pagi harinya tiriskan dan cuci potongan buah pepaya itu menggunakan air hangat, lalu tiriskan kemudian tempatkan dalam wadah bersih.

c. Buat sirup dengan cara memasak 600 gram gula pasir bersama 1 liter air selanjutnya saring. Masukkan potongan buah pepaya kedalam larutan gula ke pada wadah bersih dan biarkan terendam selama 5 hari.

d. Setelah 5 hari, tiriskan daging buah pepaya tadi dan masukkan ke dalam air panas selama 5 hingga 7 menit.

e. Berikutnya rendam daging buah pepaya menggunakan 1 gram asam askorbat yang sudah dilarutkan dalam 1 liter air

f. Tiriskan dan kemudian rendam menggunakan 1 gram Natrium Bisulfit yang sudah dilarutkan dalam 1 liter air selama 15 menit.

g. Selanjutnya rendam papaya menggunakan air larutan gula.

h. Manisan pepaya selanjutnya dikemas menggunakan cup sealer. 
2. Pelatihan Pengemasan Produk

Pada saat pelatihan pengemasan produk, instusi memberi bantuan berupa cup sealer. Adanya peralatan cup sealer membuat kemasan sudah lebih menarik dari sekedar kemasan platik klip menjadi kemasan cup yang lebih higienis dan elegan.

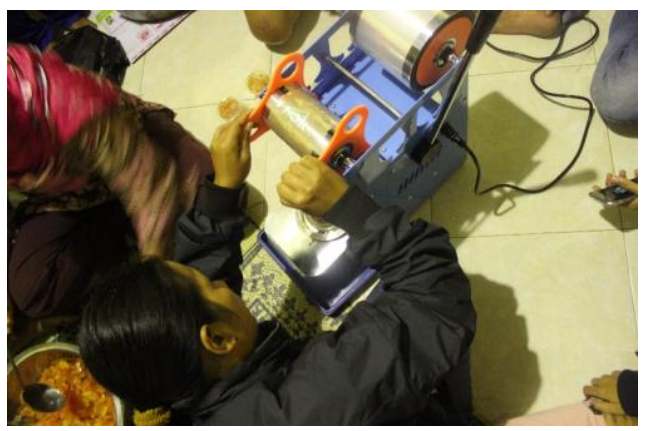

Gambar 3. Pelatihan Pengemasan Produk dengan Cup Sealer

\section{Pembuatan P-IRT}

Guna menunjang kualitas Manisan Pepaya, maka kelompok telah dilakukan beberapa upaya. Pertama, mengajukan perijinan P-IRT kepada Dinas Kesehatan Kabupaten Magelang, untuk itu proses pembuatan dan lokasi pembuatan sudah ditinjau secara langsung oleh tim dari Dinas Kesehatan Kabupaten Magelang. Meskipun sudah ada peninjauan dari Dinas kesehatan, namun proses yang dilalui untuk mendapatkan perijinan membutuhkan waktu yang cukup lama. Pada bulan Maret 2018 akan dilakukan penyuluhan oleh Dinas Kesehatan Kabupaten Magelang yang akan diikuti oleh perwakilan pengurus Manisan Pepaya Dusun Babadan. Setelah penyuluhan itu dilakukan, maka nomor izin P-IRT akan dikeluarkan oleh Lembaga tersebut.

4. Pembuatan Merk dan Label Produk

Merk dagang yang digunakan adalah Manisan Gandul, dalam perkembangannya ternyata Mitra juga melakukan diversifikasi produk dengan cara memproduksi manisan salak dan manisan nangka. Dengan demikian pada akhirnya, Kelompok PKK Dusun Babadan membuat Manisan Pepaya sebagai produk utama, dan manisan salak serta manisan nangka sebagai produk pendamping.

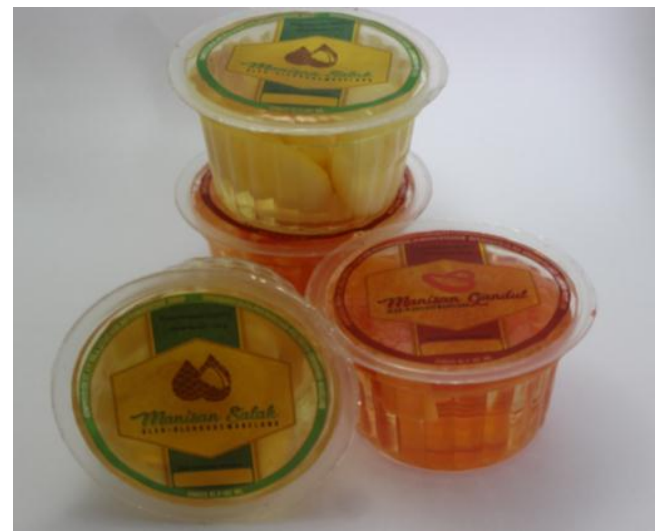

Gambar 4. Merk Produk Manisan

5. Pembuatan Keranjang Kemasan Produk

Untuk kepentingan menjangkau pasar oleh-oleh, maka dilaksanakan juga pelatihan dan pendampingan pengemasan produk yang menarik, tampak pada Gambar 5.

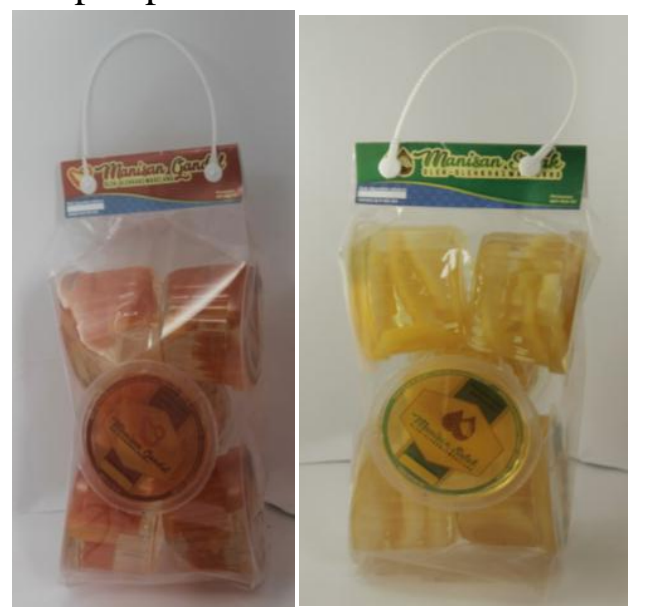

Gambar 5. Manisan dalam Kemasan Oleh-Oleh

6. Pembuatan Media Pemasaran Secara Online

Ada 4 media online yang digunakan untuk memasarkan produk yaitu:

a. Akun Instagram dengan nama akun manisan_babadan 
b. Akun Facebook dengan nama akun Aneka Manisan Srumbung Babadan

c. Akun email dengan alamat manisanbabadan@gmail.com

d. Beberapa akun WhatsApp.

Adapun admin untuk akun-akun media online tersebut adalah Ibu-ibu PKK Dusun Babadan Srumbung Magelang.

7. Pelatihan Pemasaran dan Penghitungan Harga Pokok Produksi dan Harga Pokok Penjualan

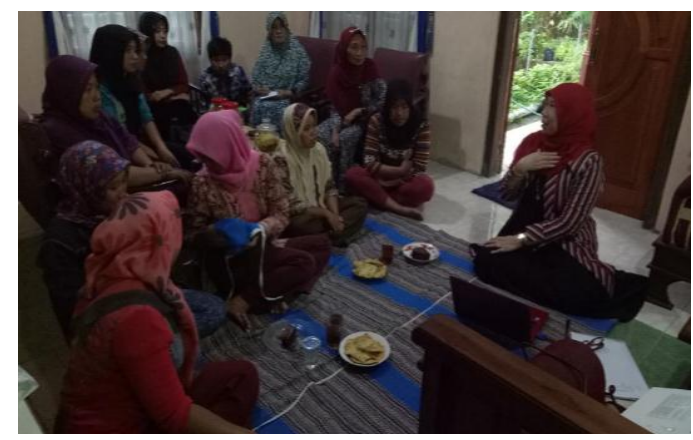

Gambar 6. Pelatihan Pemasaran dan Pembuatan Laporan Keuangan

\section{Pembuatan Plang Papan Nama}

Plang papan nama diletakkan di tempat produksi dan penyimpanan produk, yaitu di halaman rumah Ibu Rustinah selaku Ketua PKK Dusun Babadan Srumbung Magelang.

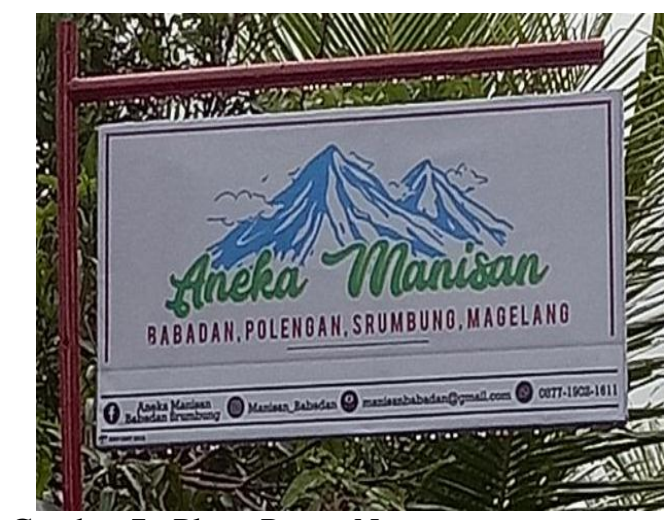

Gambar 7. Plang Papan Nama

\section{Pembahasan Hasil Pelaksanaan Kegiatan}

Hasil dari pelaksanaan Pengabdian pada Masyarakat mencakup beberapa aspek:
1. Keberhasilan target ditinjau dari jumlah peserta pelatihan (produksi dan pemasaran)

2. Ketercapaian tujuan pelatihan (produksi dan pemasaran)

3. Ketercapaian target materi sesuai dengan yang telah direncanakan

4. Kemampuan peserta dalam menguasai materi.

Target peserta pelatihan seperti direncanakan sebelumnya adalah anggota PKK Dusun Babadan yang tertarik dan berminat untuk mengikuti pelatihan produksi manisan pepaya, pemasaran, dan penyusunan laporan keuangan sejumlah sekitar 15 orang. Dalam pelaksanaannya, kegiatan ini berhasil dikuti oleh 15 orang peserta yang artinya bahwa target peserta tercapai seratus persen. Angka tersebut menunjukkan bahwa jika kegiatan Pengabdian pada Masyarakat dilihat dari jumlah peserta yang mengikuti maka dapat dikatakan berhasil.

Ketercapaian tujuan pelatihan dan pendampingan produksi manisan pepaya secara umum dapat dikatakan sudah baik bahkan melampaui target, karena disamping pelatihan pembuatan manisan pepaya juga dilaksanakan pelatihan pembuatan manisan salak dan nangka yang diperlukan sebagai produk pendamping sebagai alternatif jika calon konsumen potensial menginginkan produk lain selain manisan pepaya atau tidak menginginkan manisan pepaya, dengan demikian dapat disimpulkan bahwa tujuan kegiatan ini dapat tercapai.

Ketercapaian target materi yang disampaikan pada kegiatan Pengabdian pada Masyarakat ini berhasil dengan sangat baik, materi pendampingan secara keseluruhan berhasil disampaikan.

Adapun materi pendampingan yang telah disampaikan terdiri dari:

1. Pelatihan pembuatan manisan pepaya, salak, dan nangka

2. Pelatihan manajemen pemasaran 
3. Membuat label dan kemasan produk

4. Membuat PIRT

5. Pembuatan plang papan nama Mitra

6. Pembuatan akun facebook dan Instagram untuk Mitra

7. Pelatihan penyusunan laporan harga pokok produksi dan laporan keuangan

Kemampuan peserta dilihat dari penguasaan materi sudah sangat baik, tampak hasil poduksi dan kemasan sudah sangat baik dan menarik. Setiap hari Ibuibu PKK Dusun Babadan Polengan memproduksi manisan pepaya, salak, dan nangka. Tidak jarang Mitra juga menerima pesanan khusus.

Secara keseluruhan kegiatan pendampingan produksi dan pemasaran manisan pepaya di Dusun Babadan Srumbung Magelang dapat dikatakan berhasil. Keberhasilan tersebut dapat dilihat dari kepuasan dan pemahaman peserta setelah mengikuti kegiatan dan keberlanjutan kegiatan usaha setelah pendampingan dilaksanakan. Manfaat yang diperoleh peserta adalah dapat memproduksi produk berupa manisan pepaya, salak, dan nangka; mengemas, memasarkan, sekaligus menghitung harga pokok produksi dan menyusun laporan keuangan.

\section{SIMPULAN}

Secara keseluruhan kegiatan Program Pengabdian pada Masyarakat pendampingan produksi dan pemasaran manisan pepaya di Dusun Babadan Srumbung Magelang telah diselesaikan dan berhasil baik. Kegiatan yang sudah terlaksana adalah: Pelatihan pembuatan manisan pepaya, salak, dan nangka; Pelatihan manajemen pemasaran; Membuat label dan kemasan produk; Membuat PIRT; Pembuatan plang papan nama Mitra; Pembuatan akun facebook dan Instagram untuk Mitra, dan Pelatihan penyusunan laporan harga pokok produksi dan laporan keuangan. Untuk keberlanjutan, masih terdapat masalah untuk pemasaran secara online, karena sulitnya akses internet yang ada di Dusun Babadan Srumbung Magelang.

Waktu yang digunakan untuk melaksanakan kegiatan pengabdian sebaiknya ditambah supaya tujuan dari pengabdian dapat tercapai sebagaimana mestinya, dengan konsekuensi adalah perlu penambahan hibah yang digunakan untuk pelaksanaan kegiatan. Oleh karena itu biaya Pengabdian pada Masyarakat sebaiknya berbeda antara beberapa tim pengusul proposal, perbedaan tersebut dilihat dari khalayak sasaran, lokasi mitra, dan alat yang digunakan untuk kegiatan untuk kemudian dihibahkan kepada mitra.

Untuk kesinambungan usaha Mitra, maka perlu dilakukan kontinyuitas pelatihan dan pendampingan sehingga akan terjadi perbaikan.

\section{UCAPAN TERIMAKASIH}

Terima kasih kepada LP3M Universitas Muhammadiyah Yogyakarta yang telah memberikan hibah Pengabdian pada Masyarakat skema Program Kemitraan Masyarakat, sehingga program ini dapat berjalan dengan baik. 
ISSN : 2550-0198

\section{DAFTAR PUSTAKA}

[1] Badri, B. (2015). Analisis Potensi dan Pertumbuhan Ekonomi Daerah Kabupaten Solok. Jurnal Ipteks Terapan, 8(4). https://doi.org/10.22216/jit.2014.v8i 4.18

[2] Buchari, A. (2009). Manajemen Pemasaran dan Pemasaran Jasa. Alfabeta.

[3] Dwita, D. (2015). Televisi dan Kepentingan Pemilik Modal dalam Perspektif Teori Ekonomi Politik Media. Jurnal Ipteks Terapan, 8(4). https://doi.org/10.22216/jit.2014.v8i 4.21

[4] Harahap, K. (2016). Kebijakan Pengelolaan Keuangan Publik Pada Masa Kekhalifahan Umar Bin Abdul Aziz. Jurnal Ipteks Terapan, 8(2), 58-69.

https://doi.org/10.22216/jit.2014.v8i 2.424

[5] Kotler, P., \& Amstrong, G. (2012). Prinsip-prinsip Pemasaran (13th ed.). Erlangga.

[6] Yatim, A. (2015). Ekspektasi Pertumbuhan Ekonomi Sumatera Barat dan Tantangan Perekonomian Tahun 2015. Jurnal Ipteks Terapan, 9(1).

https://doi.org/10.22216/JIT.2015.v 9.i1.28 